\title{
Vertentes do
}

republicanismo

no Oitocentos

\section{brasileiro}

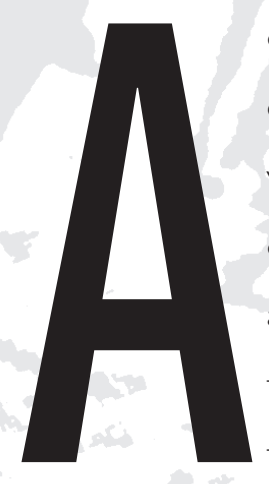

- longo da década de 1870 tornou-se evidente o fim de um certo consenso valorativo que caracterizara, até então, - Império. Após a Guerra do Paraguai, a cidade e a cultura derivada dela desafiaram a metáfora do "jardim sóbrio e firme" com que os conservadores representavam a permanência da civilização agrária brasileira. A noção de mudança, trazida então pelos liberais, impôs-se, começando por deslocar a concepção atemporal das representações tradicionais do Brasil.

De fato, esgotadas as energias revolucionárias que sacudiram o país até o final da década de 1840, as idéias de movimento, mudança e outras noções correlatas conheceriam um certo des- 


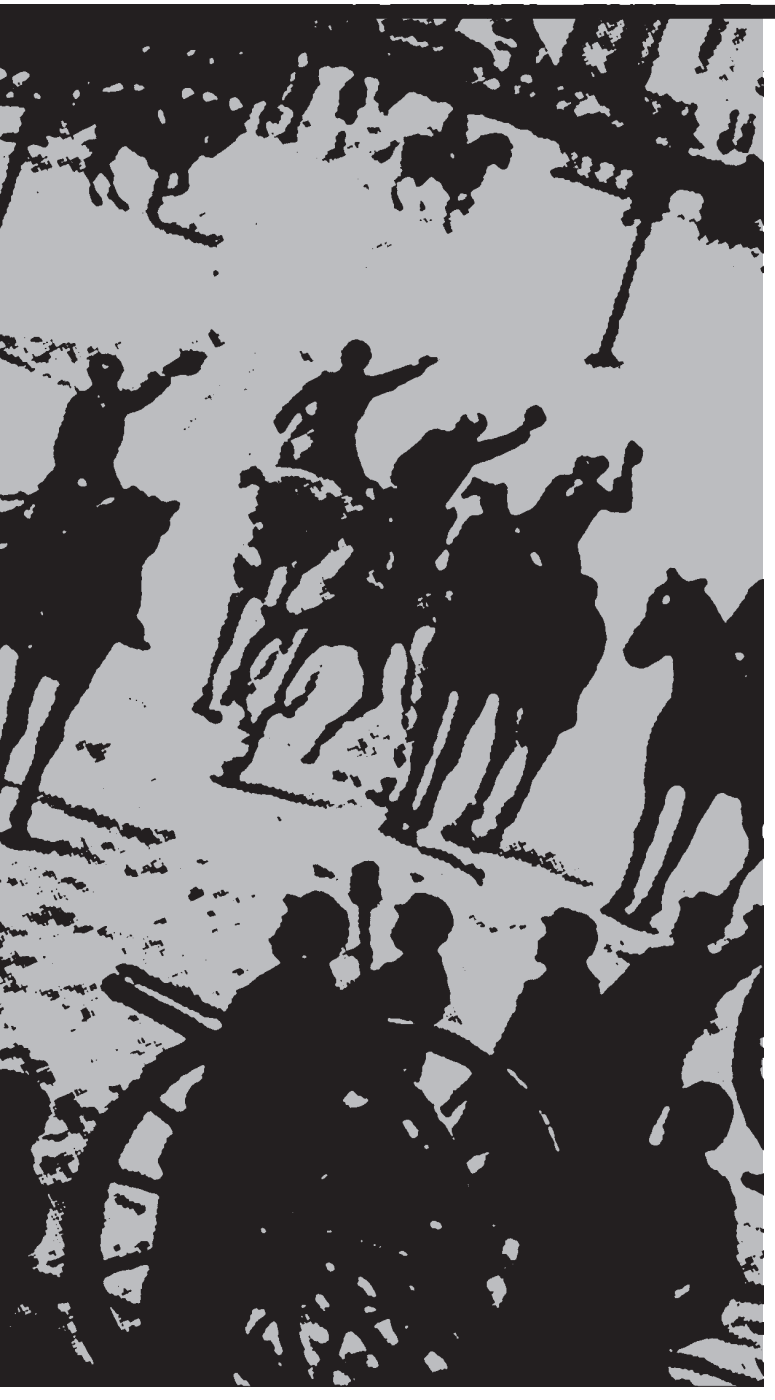

prestígio. Se a lembrança do passado revolucionado pelas paixões partidárias precisava ser apagada, a fabricação de imagens ideais do futuro, cerceada pelo recorrente medo de um descontrole semelhante era das mais limitadas. presente tornou-se, assim, o grande estuário das crenças, expectativas e representações sobre o Brasil - um presente atemporal e perene, em que Joaquim Nabuco identificará um sintoma do conservadorismo brasileiro.
A partir de 1850, portanto, o sentimento conservador se instalou de forma tão vasta que, nas palavras do visconde do Uruguai, recobriu todas as dimensões da vida brasileira - a política, primeiro, completando-se na intelectual, na moral, na material, na religiosa. Paralisados desde então, os liberais viveriam ainda mais algum tempo sob os efeitos de sua derrota, submergindo em uma cena pública desvitalizada, quase inerte, resultado da conciliação entre "moderados conservadores, desejando reformas parciais, e velhos liberais, abjurando revoluções" (I).

Aquele foi o tempo, como se sabe, de consolidação do Estado imperial, quando lideranças conciliadas e arrefecimento do ânimo partidário traduziam o curso de um processo de centralização do poder - ou, na linguagem da época, uma vitória da razão administrativa sobre as "paixões" das casas senhoriais; ou ainda, da soberania nacional sobre a "tutela de facções" que apenas cuidavam de interesses particulares, negligenciando o bem comum (2).

Pretensão de fôlego, a obra dos chamados construtores do Império - conservadores à frente - consistiu, entre outras coisas, em produzir instrumentos para o exercício de tão vasta lide-
Paulo Mercadante, A Consciência Conservadora no Brasi Rio de Janeiro, Saga, 1965, pp 163-4

As expressões são do viscond do Uruguai, extraídas de: Ensaio sobre o Direito Administrativo, 1862, apud IImar Rohlof de Mattos, "O Lavrador e Construtor - o Visconde do Uruguai e a Construção do Es tado Imperial", in Maria Emília Prado (org.), O Estado como Vocação. Idéias e Práticas Polí ticas no Brasil Oitocentista, Rio de Janeiro, Access, 1999, pp. $191-218$ 
rança, dentre eles o próprio vocabulário político, que teve alguns termos redefinidos, algumas distinções estabelecidas. Uma dessas distinções concerniu à idéia de movimento, que, à diferença de "agitação", foi agregada ao campo político conciliado. Desse modo, conservação e movimento não seriam incompatíveis - ao contrário: sua associação denotava a possibilidade de uma marcha progressiva de conquistas, que, contudo, levasse em conta a tradição, que não desconhecesse aquilo que o visconde do Uruguai tratava como as "especificidades" do país - ainda que, em sua própria avaliação, grande parte delas, fosse transitória. Pode-se entender, nesse caso, que o compromisso entre mudança e conservação referia-se, basicamente, a um método de inscrição do Brasil no curso de uma história ocidental, de sentido já previsto e consagrado, embora em registro mais amável, sem os saltos revolucionários da Inglaterra do século XVII, e da França, no XVIII.

Outra distinção importante foi aquela estabelecida entre governo e Estado imperial, cujas conseqüências institucionais - a existência do Poder Moderador, por exemplo - não são pequenas, mas não serão tratadas neste texto. Aqui será mencionada apenas a substância daquela distinção - o fato de que governo e Estado, no Império, tenham sido concebidos como instâncias apartadas e movidas por ideais diversos, já que o governo se voltava à consecução de interesses necessariamente parciais, próprios do partido ou da facção que estivesse no comando da política, enquanto o Estado imperial dedicava-se a estender a sua benemerência por todos quantos fossem e onde estivessem os brasileiros.

A consequiência mais óbvia dessa arquitetura terá sido a depreciação da política parlamentar, dos sistemas partidário e eleitoral, por parte dos grandes expoentes da elite brasileira oitocentista; a depreciação, enfim, da política com "p" pequenocomo a ela se referirá, apenas para citar um dos mais notáveis dentre eles, Joaquim Nabuco -, daquela política que gira explicitamente em torno de interesses e, portanto, enseja o aparecimento dos tristes "bair- ros políticos", com seu séquiito de apadrinhados e oportunistas.

Por fim, relacionada à diferenciação entre governo e Estado, foi a separação que o visconde do Uruguai estabeleceu entre poder político - locus, como se viu, dos particularismos - e poder administrativo, um poder apolítico, entendido como elemento de conservação e progresso, já que posto acima dos interesses de grupos para melhor "prover as necessidades coletivas". A consequiência destacável dessa associação entre poder administrativo e bem comum foi a política de interiorização de agentes do Estado no espaço territorial do Império - verdadeiro bandeirantismo de funcionários, destinado a romper o isolamento das casas senhoriais para melhor vigiá-las e dirigi-las, afirmar o controle sobre o território e integrar os homens livres, dispersos nas veredas do "Brasil de dentro", à esfera estatal.

Mas oresultado político desse empreendimento, tão importante quanto pouco destacado, terá sido a entrada em cena de um princípio de unidade operado pela monarquia - princípio esse que, em alguns momentos, terá o seu sentido vazado por ideais mais sensíveis como o de "justiça una", no contexto da abolição da escravidão, ou o de "vontade geral", empunhada pelos intelectuais reformadores do Estado imperial quando já ia alta a propaganda republicana. $\mathrm{O}$ argumento a ser fixado, nesse passo, é o de um Estado imperial progressivamente identificado com princípios de teor republicano, em sua forma e orientação.

O modelo, enfim, era o das monarquias administrativas que vicejaram no período da Restauração européia, e que tiveram como inspiração a cultura ao mesmo tempo cortesã e burocrática do Império napoleônico, com sua dinâmica centralizadora e expropriadora dos poderes aristocráticos, sua hierarquia de funcionários públicos interessados em consolidar os órgãos da administração, com sua perspectiva em alguns casos territorialista, porém sempre civilizatória, empenhada em estabelecer a presença do Estado onde parecia impossível, com sua crença na institucionalização das profissões intelectuais reguladas por 


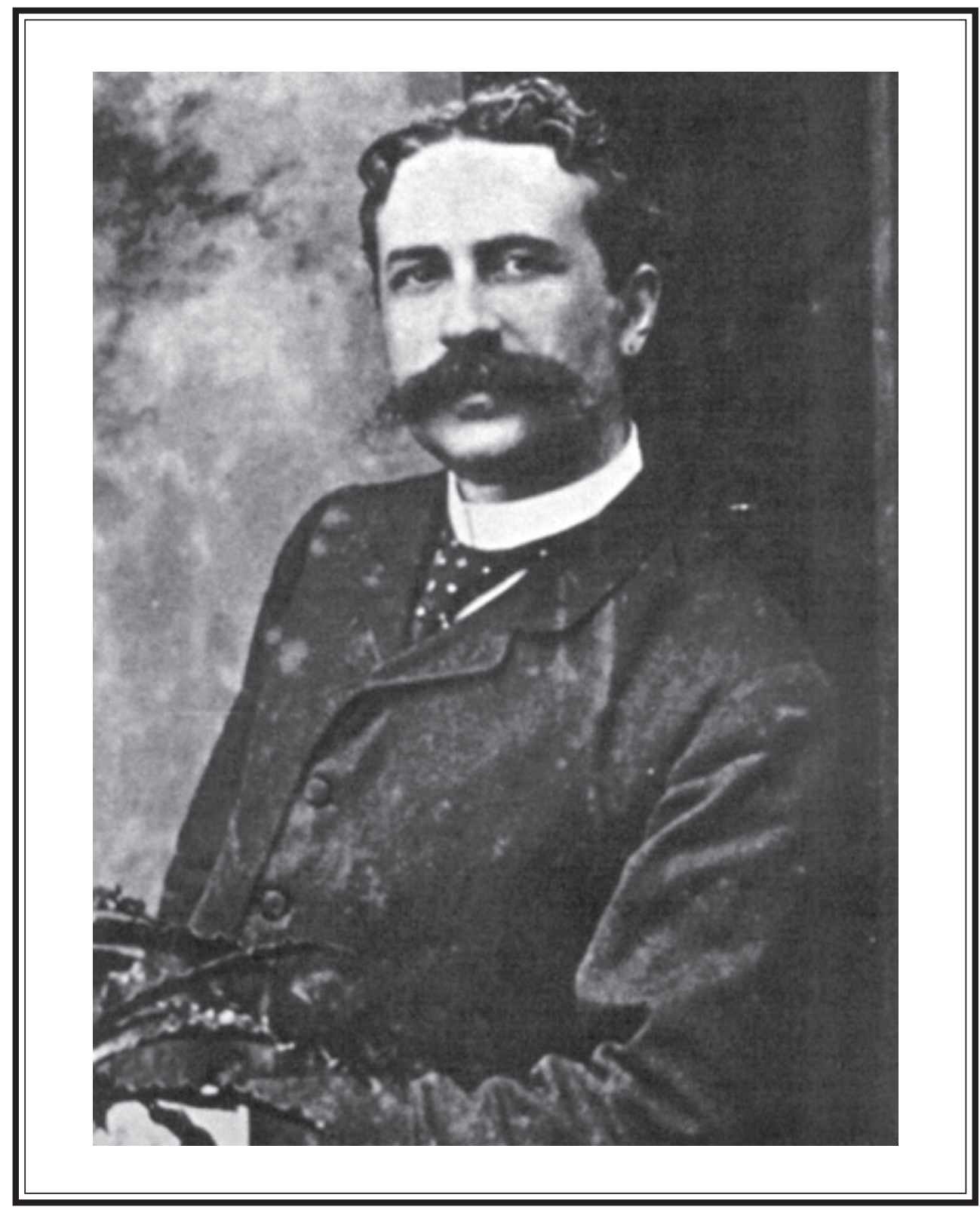

O abolicionista

Joaquim

Nabuco

institutos e academias e, finalmente, com a abertura de postos da burocracia estatal a representantes dos estratos médios da sociedade, que passaram a ser incorporados principalmente no setor militar do funcionalismo. Tal modelo, plenamente reconhecível no programa construtivo dos saquaremas e que terá perdurado, já com os liberais, até a Proclamação da República, permite inscrever a consolidação do Império brasileiro no contexto mais amplo em que tiveram curso processos de modernização de formações sociais periféricas, nos quais, dentre outras características, foi comum a atuação de intelectuais estatais, responsáveis pela aclimatação local dos efeitos da Revolução Francesa, sem, evidentemente, o concurso da revolução (3).

O fato é que o apogeu do Império brasileiro caracterizou-se pelo esforço de construção de instituições ajustadas a um racionalismo típico da cultura barroca - racionalismo de fundo teológico, segundo o qual Deus (razão suprema) seria o meio de prova das doutrinas morais, legais e políticas da vida secular. Já no contexto colonial, esse preceito neo-escolástico operou em registro político, afirmando a razão
3 Sobre o conceito gramsciano de "reação-superação da revolução francesa" nas formações nacionais periféricas, cf.: Luiz Werneck Vianna, "O Ator e os Fatos: Revolução Passiva e Americanismo em Gramsci", in A Revolução Passiva Iberismo e Americanismo em Gramsci, Rio de Janeiro, Revan, 1997. Para o caso brasileiro, cf.: Maria Alice Rezende de Carvalho, O Quinto Século. André Rebouças e a Construção do Brasil, Rio de Janeiro, 1998 , especialmente o capítulo "Três Caminhos Brasileiros-o Rinnovamento", pp. $22-46$. 


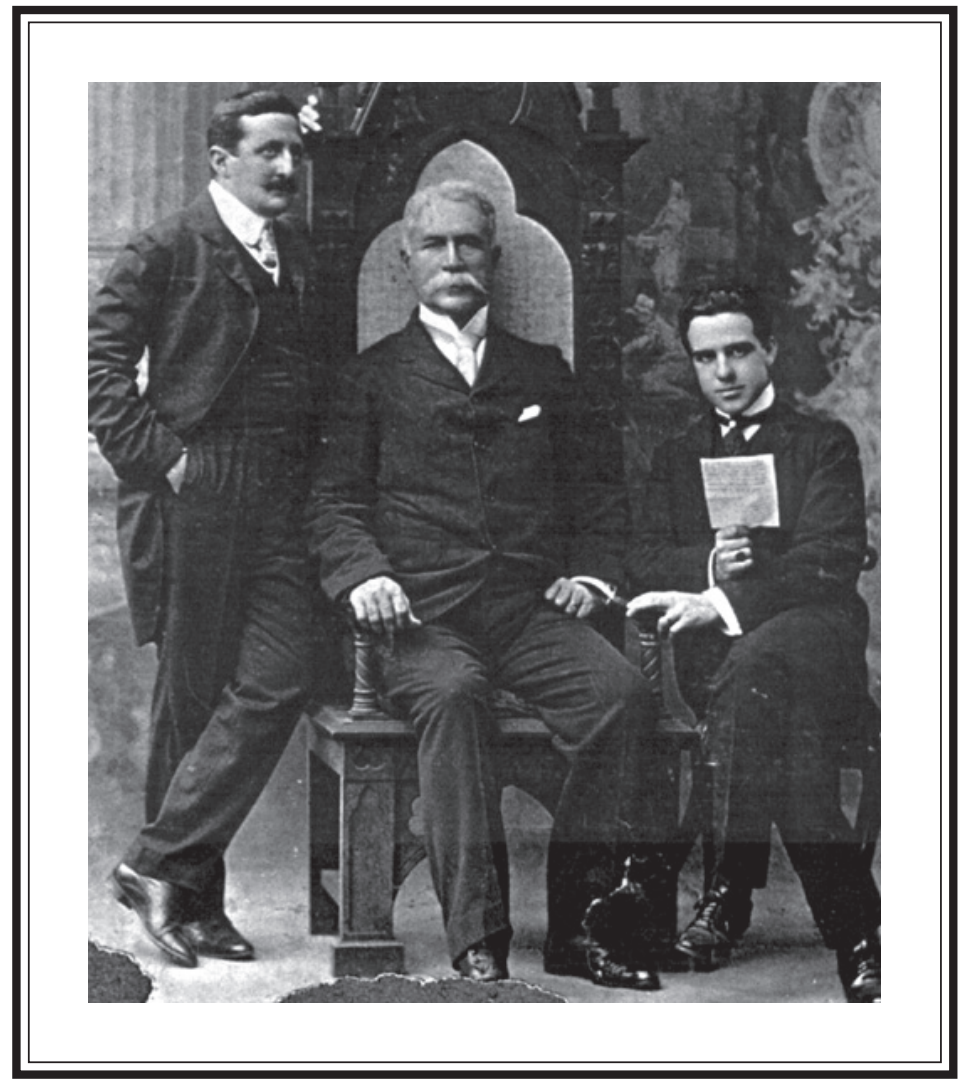

incontrastável do rei em luta contra as forças irracionais da dispersão. E, afinal, pela ação dos saquaremas, em pleno ambiente oitocentista brasileiro, assumiu a figura de uma razão de Estado que, em nome do bem comum, realiza a paz e a unificação da classe senhorial em uma ordem arquitetonicamente concebida-na base, a família patriarcal, acima dela, o patriciado dirigente e, acima deste, o cérebro, o núcleo ativo daquele edifício, representado na pessoa do imperador, critério último de avaliação da coerência entre as aspirações nacionais e a Idéia fundadora (4).

Essa narrativa nacional, que, em última instância, consignava o caráter transcendente da civilização que se erigia pela ação do imperador, ainda que extemporânea em sua epistemologia e retrógrada em sua orientação institucional estratégica - uma vez que assumiu um territorialismo "defensivo", típico dos nacionalismos europeus, quando já tinha curso a experiência norteamericana de um territorialismo fundado

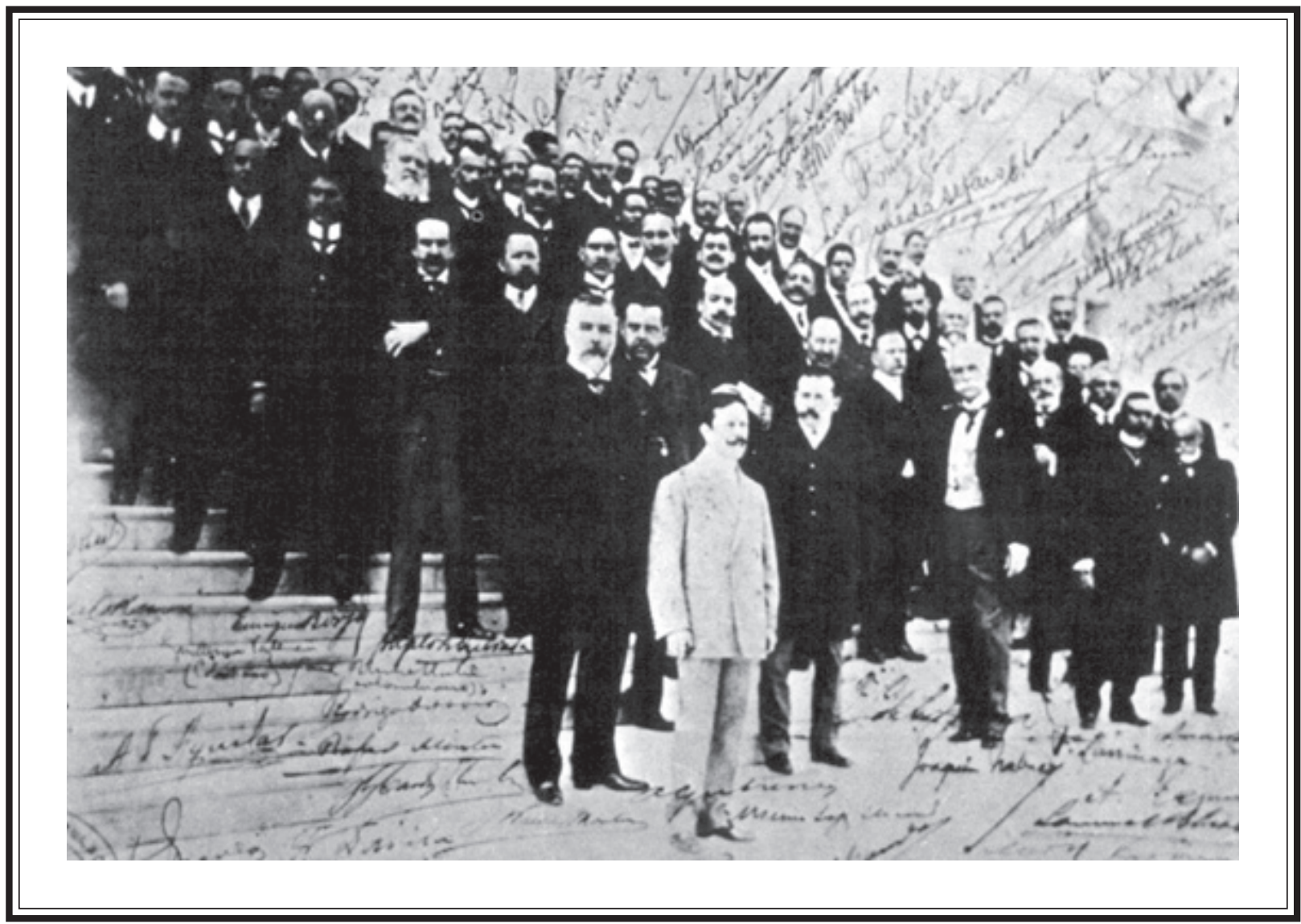


na ação coletiva de colonos-proprietários (5) -, tal narrativa, repita-se, continha, porém, aspectos que se mostraram bastante permeáveis ao imaginário republicano que se adensaria nos anos de 1870-80.

Primeiramente, porque relevou os temas do bem comum e da moralização do interesse, ou seja, chamou a atenção para a virtude contida na conversão das "paixões privatistas" em desejo de felicidade coletiva ainda que tal conversão fosse considerada atribuição do Estado imperial.

Secundariamente, porque incorporou um certo dinamismo à estrutura atemporal e naturalizada das figurações sobre o Brasil - mesmo que tal dinamismo fosse mais compatível com o tema do aperfeiçoamento, isto é, com a proposta de uma auto-reforma das instituições estatais, do que com a perspectiva da ruptura, do cancelamento do estado de coisas existente, como desejariam os republicanos.

Finalmente, porque, do ponto de vista empírico, as monarquias administrativas tenderam a favorecer o crescimento e a complexificação da vida urbana, uma vez que seus funcionários, desgarrados da estrutura agrária, passaram a viver, pensar e agir em um cenário inteiramente novo e público, como o da cidade, em que critérios inéditos de reconhecimento e prestígio começam a regular seu comportamento e a aprofundar sua autonomia em relação ao mundo de onde, quase sempre, provinham (6).

De modo que, em meados da década de 1870 , quando o carro liberal começou novamente a se mover, o tema da cidade, como metáfora fundacional da república (7), não encontraria aqui, inteiramente prontos, os atores adequados à sua filologia - afinal, a sociedade brasileira se apresentava confortavelmente assentada nos princípios da domesticidade e da desigualdade. Mas já encontraria, sim, uma certa audiência, educada publicamente, que começou a dar indícios de que a grande cultura do Império, seu repertório intelectual, a imagem, enfim, de um jardim que se repunha nos trópicos sem alterações de grande monta desde o período colonial, tudo aquilo se esgotava rapidamente.
A partir daí, duas concepções de república passaram a povoar o horizonte dos debates políticos no Império brasileiro. A primeira delas, mais forte, enunciada, não à toa, por um "radical urbano" - André Rebouças -, reeditava em grandes linhas uma tradição americanista que já circulara com Teófilo Otoni e Tavares Bastos, cuja implementação, contudo, dependia de uma transformação completa da estrutura econômico-social brasileira.

Rebouças, por aquela época, constituíra o tema do interesse individual como fundamento de uma nova sociedade, por acreditar nos efeitos moralizadores que adviriam da liberdade experimentada pelo homem comum na condução de sua própria vida e prosperidade. $\mathrm{O}$ associativismo entre indivíduos autônomos seria o ambiente social onde prosperaria a solidariedade e a boa vida. Porém, para que isso se verificasse, a república propugnada por ele deveria alterar dois aspectos básicos da ordem vigente: libertar o trabalhador - escravo ou livre - do jugo do grande proprietário e reduzir a área de influência do Estado, garantindo maior liberdade de ação aos indivíduos e de cooperação entre eles.

O limite desse novo giro americanista do final da década de 1870 dizia respeito ao fato de que, para Rebouças, a defesa da república com essas características sequer previa a possibilidade de uma revolução. Nisso Rebouças diferia de Teófilo Otoni que, na primeira metade do século, levara suas idéias às últimas consequiências. $\mathrm{O}$ fato é que, ou porque o caos revolucionário vivido no período regencial havia sido muito fortemente associado a uma fracassada “experiência republicana no Brasil” (8) e, a partir daí, o binômio república-revolução passasse a sofrer uma rejeição generaliza$\mathrm{da}$; ou porque os anos saquarema haviam cristalizado, de fato, a idéia de que a sociedade é sempre fonte de vícios, lugar das paixões privatistas, e que a sua reforma, nas circunstâncias brasileiras, só poderia vir pelo Estado; ou porque Rebouças reconhecia a inexistência de atores sociais capazes de fazê-lo, ou, ainda, por todos esses motivos, o fato, repita-se, é que ele
Na página

anterior, em

cima, Nabuco

na Academia

Brasileira de

Letras e,

embaixo, na

Conferência

Pan-Americana,

1906

4 Sérgio Buarque de Holanda, Raízes do Brasil, Rio de Jane ro, José Olympio, 1936 Richard Morse, O Espelho de Próspero, São Paulo, Compa nhia das Letras, 1988; Ruben Barboza Filho, Tradição e Ar tifício Belo Horizonte, Editora da UFMG, 2000

5 Giovanni Arrighi, O Longo Século XX. Dinheiro, Poder e as Origens de Nosso Tempo, Rio de Janeiro/São Paulo, Contraponto/Unesp, 1994.

6 Sobre a constituição de uma elite desvinculada dos interes ses dos proprietários rurais e 0 aparecimento dos "radicais urbanos" no último quartel do século XIX, cf.: José Murilo de Carvalho, A Construção da Ordem, Rio de Janeiro, Edito ra da UFRJ/Relume-Dumará 1996

7 Eric Auerbach, "La Cour et la Ville", in Luiz Costa Lima (org.) Teoria da Literatura em suas Fontes, Rio de Janeiro, Francisco Alves, 1974

8 Joaquim Nabuco, Um Estadista no Império. José Thomaz Nabuco de Araúio, sua Vida suas Opiniões, sua Epoca, Rio de Janeiro, Nova Aguillar 1975 
9 Joaquim Nabuco, Minha Formação, Rio de Janeiro, Topbooks, 1999

10 Luiz Werneck Vianna e Maria Alice Rezende de Carvalho, "República e Civilização Braśleira", in Newton Bignoto (org.) Pensar a República, Belo Hor zonte, Editora UFMG, 2000 pp. 131-54.

11 A expressão é de André Re bouças, referindo-se à concepcão republicana de Joaquim Nabuco. Cf.: Maria Alice Rezende de Carvalho, OQuinto Século. André Rebouças. op. cit., p. 170

12 Joaquim Nabuco, Minha For mação, op. cit. Ver também, sobre o tema: Maria Alice Rezende de Carvalho," Joaquim Nabuco - Minha Formação" in Lourenco Dantas Mota lorg. Introdução ao Brasil (2). Un Banquete no Trópico, São Pau lo, Senac, 2001, pp. 219-37

13 Maria Alice Rezende de Car valho, O Quinto Século..., op cit., p. 165 abdicou, tal como os demais liberais de seu tempo, de inserir no horizonte político a revolução agrária popular-democrática. Seu radicalismo, por isso, esgotou-se em círculos urbanos mais restritos, o que, algumas décadas mais tarde, daria munição à crítica de Oliveira Vianna ao liberalismo brasileiro.

A segunda concepção de república, também presente nas últimas décadas do século XIX, era mais fraca, mais precavida, mais atenta às circunstâncias locais. Dela se pode dizer que, de fato, representou uma acomodação do ideário republicano ao acervo ideal, material, cultural e político dos construtores do Império. Seu portador, Joaquim Nabuco, dificilmente poderia ser identificado com um republicano, nos moldes em que essa figura viria a se apresentar em 1889 - sua rejeição àquele personagem, aliás, não foi apenas veemente, como sincera (9).

Sua principal contribuição, contudo, foi a de conceber a república como uma “forma vazia”, e, a partir daí, tentar caracterizar, no Brasil, a substância a preenchêla. Os temas da agenda saquarema, no que ainda podiam representar a produção de um certo consenso - ou como se dizia: uma consciência única, apartidária, nacional -, fizeram-se, então, presentes. Em Nabuco, por exemplo, encontra-se a noção de mudança sem ruptura com a tradição; encontra-se também o desejo de integração ao século, sem, contudo, a importação irrefletida de soluções engendradas em outras formações nacionais; encontra-se, ainda, a defesa de uma vida pautada pela exemplaridade dos ancestrais da pátria, e não pela adoção de virtudes extraídas de uma cartilha filosófica, como a do jacobinismo; encontra-se, por fim, a crença na experiência como um marcador ideal do nosso destino, e a descrença em uma república que nasce da adesão dos homens a princípios abstratos.

Os limites dessa concepção - em que pese ter ela cumprido uma trajetória muito além do contexto em que foi originalmente produzida, sendo, mesmo, uma das linhas de força do nosso processo civilizatório (10)
- foram de natureza empírica. Em 1889, quando caiu a monarquia, caiu também a possibilidade de viabilização do ideal republicano de Nabuco - a "monarquia democrática e popular" (11). Concluiu, assim, que o movimento militar, liderado por Deodoro da Fonseca, fizera apenas desmoronar o cimo de um edifício hierárquico que era o que auferia honra aos diferentes lugares estamentais e dignidade aos indivíduos. Nabuco reconhecia, ademais, que, a república se instalara porque a base desse edifício hierárquico já se encontrava corroída, desde que a "aristocracia de maneiras" - as elites tradicionais nordestinas - fora substituída pelos novos fazendeiros do sul, com seu instinto utilitário e individualista, para quem os trabalhadores eram "iguais entre si”, porém, nada além do que "meros instrumentos de colheita" (12). Segundo Nabuco, a república vitoriosa pôde renegar os nossos costumes e teve a intenção de escrever uma nova história, produzir uma nova tradição. Vista da perspectiva do fim do século, era a morte de tudo em que Nabuco acreditara.

Derrotadas, as idéias de Rebouças e Nabuco não foram completamente superadas. Em Rebouças, por exemplo, encontrase a questão da moralização do interessepode o interesse individual constituir a base de uma república? Em Nabuco, talvez importe atentar para a idéia da república como um "método" de aperfeiçoamento permanente e progressivo das instituições e da vida social. É o que se buscará apresentar a seguir.

Nos primeiros anos da década de 1870 , Rebouças teve em suas mãos a obra de L. Reyband, Vie de Harrington (13).

Harrington representava, no debate que teve curso na Inglaterra do século XVII, a assimilação das idéias de Maquiavel sobre a fundação democrática do Estado. Ao contrário da recepção francesa, portanto, que classificara a obra de Maquiavel como uma teoria da violência, adaptada à sustentação apologética do Estado absolutista, na Inglaterra predominaria uma recepção pro- 
gressista e republicana, a que a chave puritana conferiu um conteúdo prático, de cunho revolucionário.

Assim, o puritanismo inglês - ainda não rotinizado e tornado uma parábola ética do capitalismo - conheceria a radicalidade de uma Beruf coletiva do político, que se traduziu na "revolução dos santos" (14). De modo que aquilo que foi considerado o limite da dialética maquiaveliana no cenário florentino - a polaridade entre virtú e fortuna, ou seja, entre a atualidade ética e o devir político - assumiu, na Inglaterra, um registro religioso e, por analogia à discussão sobre o livre-arbítrio, que também opunha a atualidade da liberdade e o devir da graça, resolveu-se igualmente pela ação, pelo movimento incessante a que se entregam os homens de fé, mesmo ignorando o seu desfecho.

Aquela era a Inglaterra do capitalismo nascente, em que a liberdade praticada em nome da fé ainda é potência, ainda é puro desejo de mudança; era a Inglaterra em que a virtude assumia a forma de um "povo em armas" e a fortuna se mantinha como um horizonte aberto, que ainda não se cristalizara na forma de um destino inamovível. No âmbito do pensamento de Maquiavel, a discussão se fecha nesse salto - ou seja, na constatação de que a virtude pode ser corrompida pela fortuna consolidada, pelo momento em que fossem eliminados da Cidade os seus aspectos conflitivos e, com eles, a sua potencialidade democrática.

Assim, a vitalidade da república consistiria na preservação de um contexto "aberto", no qual a liberdade praticada em nome da fé fosse ainda um horizonte, desconhecendo a forma cristalizada de uma “jaula”, de um destino inamovível. Nesse sentido, a questão republicana inglesa consistia em impedir que, tal como ocorrera em Florença, a dialética se fechasse com a cristalização da política, isto é, com a eliminação dos conflitos da cidade. E o antídoto concebido para tal problema seria um sistema de liberdades baseado na propriedade privada e em contínua expansão. A questão para os republicanos não era, pois, o isolamento da virtude em face do anda- mento do interesse moderno; mas, antes, a garantia de que o interesse, em se expandindo permanentemente, reporia as bases do conflito e impediria o estiolamento da política (15).

Em síntese, o Maquiavel republicano assimilado por Harrington exalta a religião civil de um povo em armas, capaz de fazer da virtude a garantia da república e, da propriedade, a sua base material. Sob o republicanismo inglês, a atividade virtuosa do cidadão está indissociavelmente ligada à propriedade e à permanente democratização do acesso a ela-ultrapassando, por isso, a caracterização que os seus antagonistas lhe imputaram, qual seja, a de uma reedição recessiva da noção de governo misto de Políbio. Emoutras palavras, ao atribuir uma base material à teoria dos contrapesos políticos da Roma imperial, Harrington se inscrevia entre os modernos, embora se movimentasse contra o capitalismo nascente, que representava um obstáculo à autonomização de pequenos proprietários.

Daí que, na Revolução Inglesa, o princípio republicano se apresente como uma proposta política de oposição ao status quo, e não como um ideal antigo ou uma utopia messiânica, pois ele prevê uma tradução material e cognitiva da virtude, passando a representá-la como a autonomia do homem comum, garantida pela propriedade. Em Harrington, a possibilidade de corrupção da república não derivava mais da dialética naturalista de Políbio, da necessária caducidade cíclica de um Estado virtuoso na origem, e sim da corrupção dos proprietários mesmos, pela experiência de rotinização da riqueza, pelo esquecimento do êmulo instituinte de uma sociedade democrática (16). De modo que a Constituição republicana atenderia a essa função "rememorativa", organizando a vida social em moldes que lhe permitissem continuar ampliando a esfera da liberdade; seria, nesse sentido, uma Constituição que contemplaria uma dimensão prospectiva, buscando incorporar o tempo futuro-inclusive na sua expressão espacial, associada à ampliação da disponibilidade de terras - a fim de que as virtudes da origem continuassem a
14 Michael Walzer, The Revolution of the Saints. A Study of the Origins of Radical Politics, Harvard University Press, 1965

15 Antonio Negri, El Pode Constituyente. Ensaio sobre las Alternativas de la Modernidad Madrid, Libertarias, 1994

16J. G. Pocock, "Machiavelli, Harrington and English Politica deologies in the Eighteen Century", in Politics, Language and Time. Essays on Politica Thought and History New York, Atheneum, 1973, pp. 104-47 
encontrar possibilidades de realização.

São três, então, os aspectos do republicanismo de Maquiavel incorporados ao debate inglês do século XVII. Em primeiro lugar, a idéia de fundação da liberdade, enraizando-se o tema da descontinuidade política no âmbito do conflito entre classes. Em Harrington, a guerra civil inglesa - o ápice do desentendimento - se converte em ponto de partida de uma ordem nova, permanentemente renovadora. Desse critério de renovação contínua emprestado à interpretação da vida social inglesa deriva um segundo aspecto, de natureza teórica e prática: a perspectiva constitucional do governo misto polibiano dizia respeito a um mundo estático, destituído da energia expansiva, sendo corrigida, portanto, pela perspectiva constitucional republicana, portadora de uma dimensão prospectiva.

Finalmente, o último e mais importante aspecto do republicanismo maquiaveliano incorporado ao debate inglês concernia ao fato de que a virtude fora imersa na materialidade do mundo e somente a consideração desse aspecto poderia salvá-la da corrupção representada pela transformação da liberdade-que é potência-em destino. O passo seguinte consistiu, então, em identificar a base da liberdade - a propriedade da terra - e em propor uma nova lei agrária.

A se prosseguir na caracterização do republicanismo inglês do século XVII, o tema mais relevante deveria ser o da definição da noção de propriedade. Quanto a isso, contudo, basta a consideração de que Harrington não possuía uma perspectiva burguesa e que o seu conceito de propriedade estava mais próximo da idéia de apropriação, inscrevendo-se em um regime igualitário e coletivo, garantido pela militia e pela legalidade incorporadora da república Commonwealth.

De qualquer modo, em fins da década de 1650 , a guerra civil caminhava para o seu desfecho e a sociedade inglesa conhecia alterações importantes na sua estruturação-crescia a importância das cidades e a monetarização da economia, desenvol- via-se a burocracia ligada ao Estado e emergia uma nova disposição produtiva, menos articulada à terra. Nos anos de 1660 e 1661 Harrington se entregara à militância revolucionária e terminara preso. Mas a sua derrota e a do radicalismo democrático que ele encarnara não significaram o banimento da "república dos santos" da memória popular. Ela viverá de forma latente e, pelo sentimento religioso, será alçada à condição de uma metáfora do desejo de autonomia individual e de inovação social - o cenário privilegiado dessa reconstrução revolucionária será a América.

A história do republicanismo inglês não era ignorada pelos setores educados da elite política brasileira. Nabuco, mesmo, reconhece o tema da virtude republicana a oxigenar o edifício institucional da Inglaterra monárquica. Porém, seria Rebouças a reunir, mais explicitamente, alguns dos traços do chamado republicanismo democrático, acomodando-os, não sem tensões, ao seu repertório analítico.

Em primeiro lugar sua narrativa nacional era atravessada pelo diagnóstico da corrupção do Império. Segundo Rebouças, após o término do ciclo revolucionário que perdurara até a derrota dos liberais na década de 1840, haviam rareado as energias transformadoras do país e o Brasil iniciara um processo de enrijecimento ontológico, cuja principal evidência era a ausência de estímulo para quaisquer iniciativas inovadoras. A paz e a unidade territorial - valorizadas pela inteligência cortesã como obra do gênio político nacional - eram consideradas por Rebouças como manifestação de um ordenamento oligárquico que se fixara precocemente, como expressão do nosso destino.

Naquele Império, contido e limitado, cresciam as vozes da conciliação política, enquanto a sociedade, desde o topo até embaixo, vivia os sinais da degenerescência: “o parasitismo dos miseráveis é filho bastardo do parasitismo dos teocratas, dos oligarcas, dos aristocratas e dos plutocratas. O parasitismo superior cria o parasitismo inferior; depois ambos concorrem para atrofiarem e esfacelarem a criatura 
humana pela preguiça, pelo ódio ao traba1ho, pela cobiça abjeta de viver às custas de outrem nas camadas sociais, ou mesmo nas células das prisões. Porque há desgraçados que chegam a tal grau de aviltamento que preferem a casa de correção à oficina do trabalho" (17).

Derivado dessa avaliação do Império, o segundo traço do radicalismo de Rebouças consistiu em introduzir o argumento do conflito entre classes na crítica ao poder imperial. Nas suas palavras: “o ideal aristocrático é o Estado [...] servindo de fecho à enorme abóbada, cujas aduelas são os monopólios e os privilégios oligárquicos, e cujos pegões são formados pelos miseráveis, pela plebe, pelos proletários, argamassados na escravidão, na servidão da gleba, no salariato forçado e nos inúmeros sistemas de exploração do homem pelo homem".

Assim, tal como no radicalismo inglês do século XVII, a república para Rebouças se definia como um movimento de instituição da liberdade plebéia, conferindolhe expressão material. Em uma série de artigos publicados no Cidade do Rio, jornal de propriedade de José do Patrocínio, entre os meses de junho e julho de 1888 , ao criticar o avanço do movimento republicano dos latifundiários de São Paulo, o engenheiro avançará uma definição alternativa de república: “a nossa república, a república ideal virá no devido tempo, quando não houver mais landlords, quando tiverem desaparecido os monopolizadores da terra, quando for impossível a impunidade feudal [...]. Se não for assim, então é infinitamente melhor a monarquia popular e democrática de Joaquim Nabuco, opulenta de aspirações nobres e altruístas, bem ciente e muito consciente de que não deve haver Irlandas no continente americano..."(18)

Em Rebouças, o tema da liberdade se associava à idéia de propriedade - a grande força capaz de transformar em cidadãos os "brasileiros deturpados pela miséria e pela subserviência, por caboclos e caipiras, moradores, foreiros e residentes, por outrora comensais, guardas nacio- nais, espoletas eleitorais, mandatários de assassinatos, servos da gleba prontos a morrer e matar ao aceno da aristocraciaterritorial-negreira" (19). Aqui, portanto, Rebouças aproxima-se do republicanismo inglês, ao enfatizar a dimensão coletiva do Estado e ao afirmar a propriedade como fundamento material da construção da república - "só há liberdade na democracia rural, no lavrador-proprietário, no operário da terra absolutamente livre ou independente..." (20).

Contudo, o aspecto que distinguia o radicalismo de Rebouças daquele que prosperou na guerra civil inglesa foi, como já se disse, o fato de que ele tinha na paz um imperativo. De modo que o engenheiro não conferiria à plebe, à população de homens pobres, sem acesso à propriedade da terra, a virtude de um "povo em armas" que se organiza como poder constituinte.

De fato, Harrington lhe chegara como parte do movimento de idéias produzido por reformadores do século XIX, para os quais o liberalismo deveria ser repensado à luz das novas questões trazidas pelo desenvolvimento urbano-industrial. Salvavamse os seus fundamentos, mas a dramaticidade ética vivida na hora inaugural das liberdades havia sido aplacada, rotinizada, em uma pragmática que apagara a dimensão agonística inscrita na sua origem.

A idéia, portanto, de reforma era a tradução - já agora bastante disciplinada dos valores que partejaram o mundo moderno. Por ela passava o tema do acesso das grandes massas de miseráveis dos países capitalistas centrais aos direitos sociais - o que, em Rebouças, assumia a forma análoga da extração da questão agrária da chave revolucionária da militia - com a sua conotação radicalmente cívica-para acomodá-la a uma versão modernizadora das relações sociais no campo. Evidente que no Rebouças reformador a dimensão política implicada no monopólio da terra era percebida, tal como atesta a já citada caracterização da quebra desse monopólio, como única via de acesso do homem comum à cidadania. Porém a forma de realizá-la não seria pela revolução - aliás, segundo Rebou-

\footnotetext{
17 André Rebouças, Orfelinato Gomes de Araúio, apud Ma ria Alice Rezende de Carvo tho, O Quinto Século ..., op cit., p. 169.

8 Idem, "Republiquistas - Parte III", in Cidade do Rio, Rio de Janeiro, 27 de junho de 1888

191 dem, "Republiquistas - Parte II", in Cidade do Rio Rio de Janeiro, 16 de junho de 1888

201 dem, "Colonização da Algéria", in Revista de Enge nharia, n. 237, Rio de Janeiro julho/1890, pp. 149-62
} 
ças, um recurso bem mais compatível com a aristocracia do que com as classes trabalhadoras-e, sim, pela auto-organização de colônias de pequenos proprietários livres, istoé, pela aclimatação local de uma “ontologia espacial da apropriação” (21), que, na América, resultara da cultura inconformista portada pelos primeiros colonos.

De fato, a solução da fronteira norteamericana demonstrara ser uma via de afirmação da natureza expansiva e universalista do ideal republicano que animara a guerra civil inglesa, destituída, ademais, do caráter de urgência e de conflitividade aberta presente na concepção maquiaveliana da política. Ao aprofundar as questões sobre o monopólio da terra e estabelecer a impropriedade da militia como poder constituinte de uma nova lei agrária brasileira, Rebouças, muito rapidamente, reconhecerá na ontologia norte-americana a expressão de uma radicalidade social que prescindira do gesto revolucionário - os sujeitos da política são, ali, as massas de proprietários livres.

Nessa recorrência, porém, Rebouças não ignorou o fato de que aqueles colonos foram o resultado da derrota popular no âmbito da Commonwealth e que, portanto, o sentido da colonização aninhara a memória coletiva da invenção, da apropriação e da liberdade. Além disso, a propriedade pudera ser o critério da política porque lá ela fora arrancada como experiência inaugural do próprio direito em terras americanas. Na América, como o direito precedesse a Constituição, essa seria apenas o ato de rememoração do consenso democrático das grandes massas de proprietários, erigidos em expressão permanente do poder constituinte.

No Brasil, diversamente, descartada a hipótese da revolução agrária, a práxis da apropriação territorial ficaria dependente do legislador, da sua iniciativa de liberação da terra - o que repunha, dramaticamente, a dimensão da política. Essa, portanto, a tensão presente no americanismo de Rebouças - no Brasil, a realização da América supunha a recorrência a atores políticos que não eram socialmente homólogos a ela - aristocratas, funcionários do Esta- do imperial, políticos, enfim, que deveriam corrigir, de cima para baixo, o andamento da modernização cidadã do país. Aqui a América, para se realizar, dependia do Estado.

Ainda hoje - e de modo mais intenso no contexto em que viveu Joaquim Nabuco - o ideal republicano aparece, em geral, associado à Revolução Francesa de 1789 , momento em que a sociedade de Corte ruiu sob a pressão revolucionária do Terceiro Estado. Assim, em virtude da radicalidade do seu momento fundacional, a solução republicana francesa teve obscurecidas as suas semelhanças em relação à solução processualista inglesa, isto é, tendeu a desconsiderar a progressiva institucionalização política do seu sucesso ao longo de todo o século XIX, do que é exemplo a monarquia constitucional de Luiz Felipe, que, se por um lado reconduziu ao poder a nobiliarquia francesa, não pôde, por outro, desconhecer a força da presença burguesa naquela sociedade civil.

Originária da ação jacobina na França, a moderna idéia, portanto, de república remete, frequientemente, à de revolução, ocultando, nesse caso, o longo processo de sedimentação "passiva" das transformações que se operaram no âmbito social e que terminariam por levar as forças do Terceiro Estado a se converterem em classes politicamente dirigentes. Contra aquela definição mais estrita de república, Norbert Elias, por exemplo, acentuou o caráter transformista do processo europeu - o caso francês incluído-, considerando um tanto exagerada a avaliação de que as sociedades européias oitocentistas já ostentassem um franco predomínio burguês. Para ele, a substituição da direção política dos grupos dinásticos e aristocráticos por classes médias e trabalhadoras ter-se-ia processado até, pelo menos, o final da Primeira Guerra Mundial.

Desse ponto de vista, a visão dos anglófilos franceses do período da Restauração européia e do próprio Nabuco era ex- 
traordinariamente inovadora, ao conceberem a república como resultado de um alargamento da esfera pública, que a tornaria institucionalmente permeável à livre manifestação da "vontade geral", e não como uma forma política obrigatória. O elogio que faziam à monarquia constitucional inglesa é uma ilustração satisfatória dessa dissociação entre a república, tal como efetivamente existia, e a sua manifestação original, dramatizada no contex to da Revolução Francesa. Além disso, no caso específico de Nabuco, a idéia de "republicanização" do Brasil nem de longe implicava uma sugestão de mudança na forma de governo, sendo, aliás, a República de 1889 condenada por ele, exatamente por representar uma vitória do "argumento utilitário" sobre a "consciência pública" (22), em uma inversão completa do que deveria ser o compromisso republicano com o bemcomum e do que, afinal, fora efetivamente a agenda civilizatória do Império.

A questão, contudo, da permeabilidade da esfera pública, sob qualquer forma de governo, à manifestação da "vontade geral”, quando transposta para o Brasil, conhecia algumas dificuldades. Ela esbarrava, aqui, na inexistência empírica - mas também normativa, no caso dos segmentos reformistas da intelligentzia brasileira-de um ethos revolucionário, de uma ampla sedimentação da cultura da liberdade e da igualdade, que ancorasse o republicanismo na base da sociedade, e não apenas no edifício institucional. Sem uma animação plebéia, que, “de baixo para cima”, vitalizasse as instituições e preservasse o impulso de "publicização" da monarquia brasileira, os intelectuais reformadores seriam levados a assumir um papel "substitutivo" das classes, de vezo aristocrático e moralizador. Quanto a isso, a propósito, poder-se-ia mencionar não apenas a auto-representação de Nabuco como portador de um "mandato da raça negra [...] para protestar perante a história", como também a sua convicção de que, deixada livre, a classe politicamente ativa no Brasil reproduziria as circunstâncias de uma sociedade de privilégios, sendo necessária ao país, mais do que uma “vida vegetativa", sustentada na satisfação privada dos interesses, uma "vida moral". No Brasil, portanto, a adesão à via inglesa de modernização-e, inclusive, às suas instituições - não dispensaria um Estado ético, de modelagem aproximada à que resultara, programaticamente, do idealismo filosófico alemão, isto é, posto acima dos interesses das classes e capaz de encarnar a Idéia universal, a noção republicana do bem-comum.

O dilema, então, de Nabuco, mas não apenas dele, seria exposto, como se viu, por André Rebouças, que, embora igualmente refratário à solução dos impasses brasileiros com base em uma revolução nacional-popular, tinha claros os limites do "republicanismo" local, notadamente no que se referia ao esvaziamento da dimensão plebéia que estivera presente no seu contexto de origem e à eliminação da idéia de "conflito entre classes" como elemento indissociável do próprio Estado republicano. Sem esses elementos, não só o republicanismo monárquico seria frágil, como a Proclamação da República não resultaria na extirpação do vezo aristocrático inscrito na formação estatal.

Nabuco, na chave de Rebouças, era associado a uma monarquia democrática, que inscrevia o tema popular nas suas "aspirações", e que, por esse motivo, era superior à república desenhada pelos cafeicultores paulistas. Faltava, contudo, o fundamento material que extrairia o republicanismo brasileiro do campo semântico aristocrático - a democratização da propriedade da terra-, sem o que o bem-comum continuaria a ser perseguido pelas nobres e altruístas convicções da nossa intelligentzia, melhor ou pior sucedida, de acordo com o contexto, em seu esforço de internalizá-las na dinâmica institucional.

De qualquer modo, o retorno a $\mathrm{Re}$ bouças, neste passo do texto, cumpre apenas o objetivo de apontar o caminho que acabou prosperando na grande marcha da modernização brasileira. Nãofoi, certamente, o apontado por ele, aproximando-se bem mais das concepções de Nabuco, que, tendo conferido ao Estado uma atividade
22 Joaquim Nabuco, Minha Formação, op. cit. 
modeladora da sociedade civil, antecipara a solução republicana que acabaria vingando após 1930.

Assim, a sobrevidapolítica de Nabuco refletiria, igualmente, o seu acerto no interior do campo teórico que elegera. Anglófilo, como Rebouças, sua referência não seria, porém, a Inglaterra dos santos, de Harrington ou do republicanismo radical. De fato, Bagehot, enfaticamente citado em Minha Formação, correspondia a uma recuperação, no século XIX, das idéias de Montesquieu, outro anglófilo que, no século XVIII, relevara o nexo necessário entre as características "espirituais" dos governados e a legitimidade conferida a determinadas formas políticas: da virtude cívica derivaria a república; da honra, a monar- quia constitucional moderna; do medo, o despotismo. Tais princípios de governo, formulados no quadro mental do Iluminismo, operariam como "esclarecimentos" úteis à intervenção dos estadistas sobre as instituições e, por extensão, sobre os valores e as práticas sociais, entendidos como mutáveis e passíveis de aperfeiçoamento.

Nabuco vira, ali, a possibilidade de conciliar, no plano político a conservação institucional com os valores da reforma algo impensável na sociedade francesa, tão marcada por ideologias e valores absolutos. Escreveu Nabuco:

"O que dirige o espírito de progresso [na Inglaterra] é o espírito de realidade, espírito prático, positivo, que se manifesta pela
$\mathrm{O}$ engenheiro

André

Rebouças

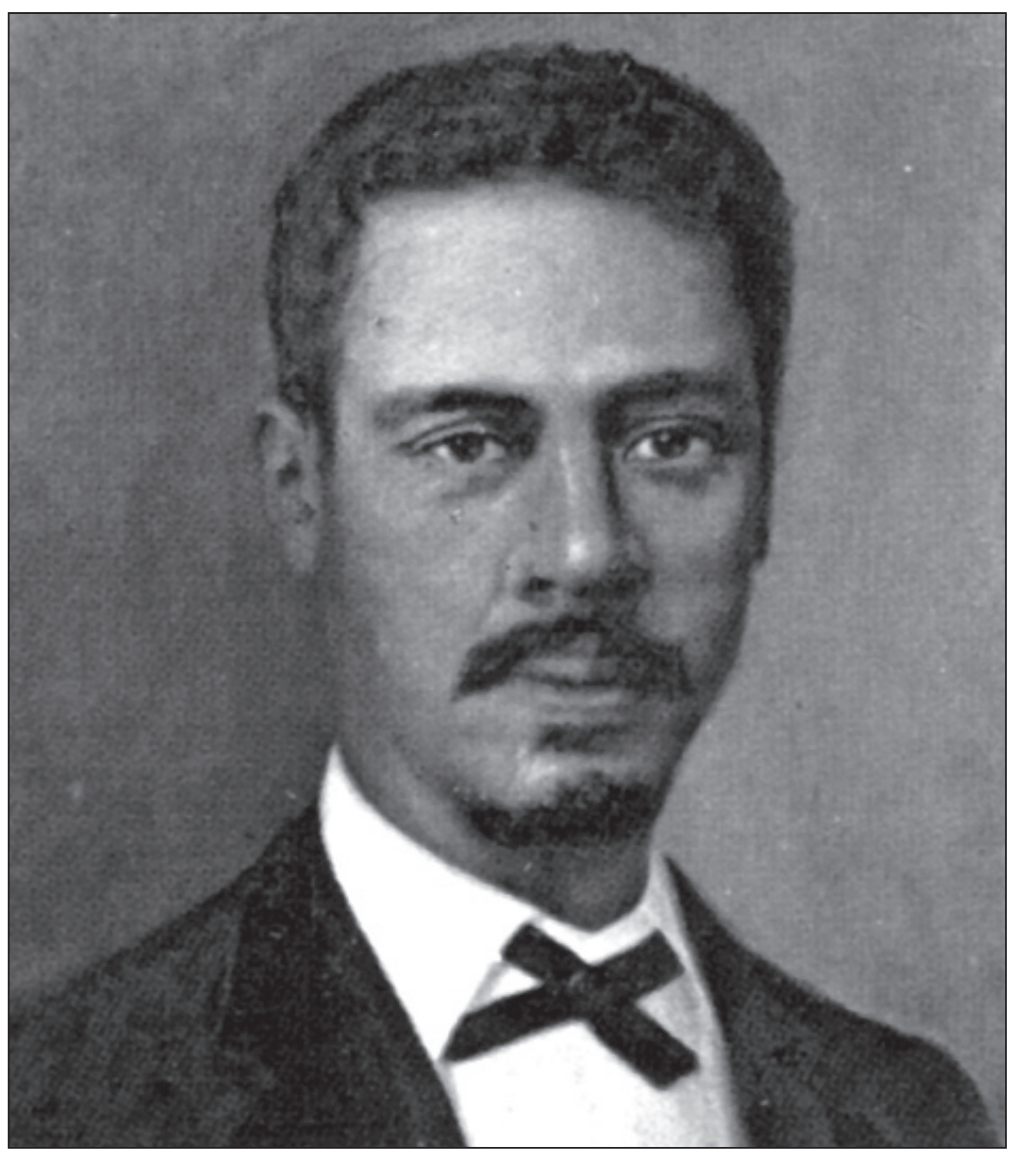


rejeição de tudo que é teórico, a priori, tentativo, lógico, ou que tenda à perfeição, à finalidade, à uniformidade, à simetria. A esse espírito corresponde, na ordem política, a idéia de crescimento: as instituições têm o seu hábitat como as plantas, as suas latitudes e terrenos próprios, condições especiais de aclimação, obstáculos e perigos de aclimatação" (23).

Sob a lente de Nabuco, então, tratavase de promover o auto-aperfeiçoamento do Estado monárquico, a fim de que ele pudesse, a partir de uma racionalidade jurídico-política, atuar sobre os valores correntes, aperfeiçoá-los e atenuar, progressivamente, o privatismo predatório dos oligarcas, sem se ver deslocado pela forma republicana de governo. Contra os "poderes locais", portanto, o centro monárquico; e, com ele, a ordem racional-legal, o civismo, a civilização e o caminho para a afirmação da liberdade.

Entretanto, como se sabe, após a Proclamação da República, a agenda civilizatória dos intelectuais liberais do Império, ainda que pudesse ter tido, no contexto anterior, uma realização autocontida e intrinsecamente hipotecada à ordem patrimonial, foi ainda mais limitada pela chamada "política dos governadores" - uma espécie de reconhecimento, no plano institucional, da oligarquização do país. O liberalismo que, no Império, impusera uma certa contenção ao poder local e ao "barbarismo vistoso dos caudilhos", como afirmou o monarquista Eduardo Prado, viu-se cristalizado em uma ideologia de elites, destituído das suas funções “pedagógicas” e esquecido da sua atribuição tradicional de superpor a lei ao arbítrio. Viu-se, por isso, reduzido a uma dimensão vazia, com o direito se aviltando em um maneirismo de bacharéis, em óbvia descontinuidade com a cultura que o concebera como a grande força ideal que presidiria as transformações moleculares necessárias à modernização do país.

Desvitalizado e destituído das suas potencialidades universalistas, em termos de direitos civis, o ideário liberal mostrar-se-ia também incapaz de incorporar os novos setores sociais, empresários, militares e operários, levando a que, nas análises vitoriosas à época, fosse necessária uma ação interventora do Estado, que livrasse o país do estrito círculo de comando a que estava submetido. Novamente, às vésperas de 1930, o diagnóstico sobre as condições propiciadoras de uma mudança das tristes circunstâncias brasileiras enfatizaria o necessário fortalecimento do público contra a sua privatização, visando restituir ao Estado a capacidade de operar com autonomia em relação aos interesses particularistas. É claro que a intenção civilizatória alterara, sob certos aspectos, o seu curso, voltando-se, então, para uma pedagogia cívica mais abrangente, do ponto de vista social, compatível com as mudanças estruturais que tinham transformado a composição demográfica e ocupacional do Brasil à época. Tal pedagogia, nesse sentido, teria como pedra de toque a conformação de uma ética social centralmente vinculada ao mundo do trabalho.

Novamente, portanto, o cenário de fragmentação e insociabilidade, dessa vez resultante do liberalismo oco das elites e de sua impermeabilidade à incorporação social e civil dos novos atores da vida brasileira, levaria à imposição de uma sociabilidade ditada pela intelligentzia reformadora, que, pela criação do direito, assentasse as instituições que deveriam aproximar os indivíduos do Estado. A república seria refundada, então, com base em uma educação cívica, orquestrada, regulada e administrada pelo direito do trabalho e suas instituições. Na década de 30, conquanto a vida institucional brasileira tivesse alterado a natureza e o sentido da institucionalidade que presidira a construção do Estado-nação, seria dela que se alimentaria o processo civilizatório do país.

O grande legado do Império, a cultura política que associara o direito à civilização, voltava à cena. Com ela, Joaquim Nabuco e a aposta em uma "republicanização" progressiva de nós mesmos, na lenta marcha que tem sido a moderna história brasileira. 